\title{
TECHNOLOGY ACCEPTANCE MODEL (TAM) ANALYSIS OF THE USE OF OVO APPLICATION IN F\&B SERVICE INDUSTRY IN INDONESIA
}

\author{
Reyner Ditya Susanto ${ }^{1}$, Raynald Tjandinegara ${ }^{2}$, Vido Iskandar ${ }^{3^{\star}}$, Endo Wijaya Kartika ${ }^{4}$ \\ 1,23,4 Management Department, Faculty of Business and Economy, Petra Christian University, \\ Indonesia \\ *Corresponding Author's e-mail: vido.iskandar@petra.ac.id
}

\begin{abstract}
This study aims to determine factors that influence user's behavioral intention in using OVO as payment method in F\&B industry in generation $Z$. The result of this research shows that Perceived usefulness will have direct influence in increasing user's intention to use OVO and indirect influence by increasing user's attitude which will strengthen the connection between perceived usefulness and behavioral intention. Perceived ease of use is proven to be not significant in increasing user's intention directly. But perceived ease of use will increase user's positive attitude first toward the usage of OVO which will eventually increase people's intention toward using OVO as payment method in F\&B industry.
\end{abstract}

Keywords: Technology Acceptance Model (TAM); OVO; F\&B service; Generation Z

\section{INTRODUCTION}

The development of the Electronic Wallet (E-Wallet) application or as known as mobile payment was first introduced in Indonesia by Telkomsel in 2007 that named T-cash (Febria \& Oktavio, 2020). However, the development of mobile payments peaked in 2017 as introduced by various new mobile payments as Go-Pay, OVO, Shopeepay and many more. above various of mobile payments, OVO is one of many mobile payments with largest transactions in Indonesia. Since introduced in 2017 , OVO become one of the largest mobile payment platform with market share of $37 \%$ of all similar platforms in Indonesia in 2019 (Aria, 2019). The development of the OVO application in Indonesia can due to various factors such as the ease of payment offered, the point system, to the fact that the OVO application commonly used to 
pay for various transactions need from paying phone bills, or even pays transactions in various industries, which is the Food and Bererage service industry is one of it (F\&B service). F\&B service could be defined as one type of F\&B industry that provides food and beverage from preparing food ingredients, processing to serve food to the guests (Cousins et al., 2019). The increase in OVO applications in the F\&B service industry can be seen from the increase in transactions in Indonesia. President Director of OVO was state that in 2019 , there was an increase of $70 \%$ in annual gross transactions with the number of transactions reaching 1 billion rupiah and the majority of the user came from food and beverage sales partners (Annur, 2020). In addition, the number of OVO application user has also increased by up to $40 \%$ so that in 2019, OVO is also available in 405 cities in Indonesia and has 115 million user.

The largest of OVO application user nowadays are from Generation Z, which was Generation Z has 40\% of active user from 2020 (Gupta \& Arora, 2019). According to the definition, Generation Z is a generation that was born in 1995-2000 (Putri et al., 2017). The high penetration of Generation Z as OVO user is because of Generation Z known technology since they are in very young age. There are 2 factors that drive user intention $(\mathrm{BI})$ towards a technology, namely very early perception. These characteristics make Generation Z are unique compared to other generations, namely generation $Z$ has higher expectations, has no brand loyalty, they even prefer instant things and is more concerned with personal experiences (Mohammed, 2018).

Generation $Z$ unique characteristic compared to another generation encourage researcher to measure factor that influenced mobile payment usage especially OVO applications in Generation Z in F\&B service industry. There are many ways that can be done to measure technology acceptance factor. One of many methods that commonly been used by academics are using Technology Acceptance Model (TAM). TAM was invented by Davis (1989) to measure people's acceptance in technology. In research, the use of OVO applications in the F\&B service industry, TAM is one most suitable models to used. This is affected by OVO application that is improving and increase a new feature that made OVO an application that is easier to use and bring many benefits to its user. In addition, the users of 
TAM model are carried out by the nature of the community who sees the benefit and conveniences that has been brought by the technology even before raising their intention to use the technology (Latief \& Nur, 2019). A technology that is easy to use and bring benefit to its user, will create a comfortable feeling that makes the user want to use that specific technology instead of using another technology. User friendly and benefit are the main concept that measured by TAM model so this research is use TAM model to measure acceptance of OVO application for paying in the F\&B service industry in generation $\mathrm{Z}$.

TAM is a model that developed by Davis (1989) from TRA model that has been developed by Hill et al. (1977) that specifically to public acceptance, especially in the field of technology (Davis, 1993). TAM are developed to aim of explaining a factor that determine people acceptance in a technology in general and explaining why about a system from that technology can be affected people acceptance (Davis, 1993). In other words, TAM can be used to explain why so many technologies can be success or failed to implemented in society. Davis (1989) stated that there are 2 main factors that affected people acceptance of a technology. These factors are perceived ease of use (PEOU) and perceived usefulness (PU). Perceived ease of use (PEOU) is a factor that measures public acceptance of the ease of operating the technology and perceived usefulness is a factor that measures public acceptance of the functions and benefits provided by the technology in helping its user's work (Davis, 1989). When both of those factor is owned by the user, a positive attitude will formed by the user towards the technology. perceived ease of use (PEOU) and perceived usefulness (PU) and attitudes of the user will directly shape an intention to use a technology.

By its definition, perceived usefulness is a person levels of believe in a technology system that technology are capable to improve working performance of its user (Davis, 1989). When someone feels that there is a technology that helps the job of its user, the user will use those technologies in the future as well, and vice versa, when somebody feels that a technology doesn't have any value or use for the user to help the works, those technologies will be abandoned (Latief \& Nur, 2019). Davis (1989) formulated in his research the technology acceptance indicators that has been used to measure perceived usefulness from a technology 
are increasing speed of works; improve job performance; increase productivity; improve efficiency; and making job task easier.

Davis (1989) in his research defined the perceived ease of use as the level of somebody's confidence of using a particular system by not requiring any effort to use it. Perceived ease of use is considered an important factor where a technology is perceived as easy by user, the functions and benefits of the technology will easily felt by the user (Davis, 1993). A system will more often be used shows that those system is easier and more user friendly to the user, on the other hand if the user felt that those technology are not user friendly, those technology are going to be abandoned and the user will look for another options that are easier to use and bring more benefits (Apidana et al., 2020). Davis (1989) in his research to formulate indicators of perceived ease of use that are used to measure the level of user ease in an application, namely easy to learn; easy to control; clear and easy to understand; flexible; and easy to master.

User attitude while using a technology can be defined as a person attitude that emerge from positive or negative feeling by those person that is result from their experience of using specific technology (Ajzen, 1991). Those positive and negative feeling will push somebody's attitude to take an action of using those technologies so that person will repeat to use those technology, meanwhile on the other side there is a negative feeling that will appear by using those technology, those feeling will push the user to find alternate technology. Wu \& Chen (2017) on their research indicators needed to formulate user attitudes towards a technology as follows great idea; wise idea; and satisfy by using it.

Nguyen et al. (2019) defined that user intent as how hard and how much effort a person is willing to put in to perform a particular behavior. In the TAM approach, a person's intention in using a technology is formed by a positive attitude that person has, and a person's perception of a technology that a technology is easy and has many benefits for him (Nguyen et al., 2019). Whereas someone feels that a technology is easy to use, is useful for him and creates positive feelings for them, then those factors will create an intention for him to use the technology. Conversely, when someone feels that a technology is difficult, it does not bring 
benefits and creates negative feelings, then the intention to use the application repeatedly will be small. Kucukusta et al. (2015) in his research to formulate the indicators needed to formulate the intentions of one's user towards a technology as follows planning for future use of technology; planning for regular use; and recommendations to others.

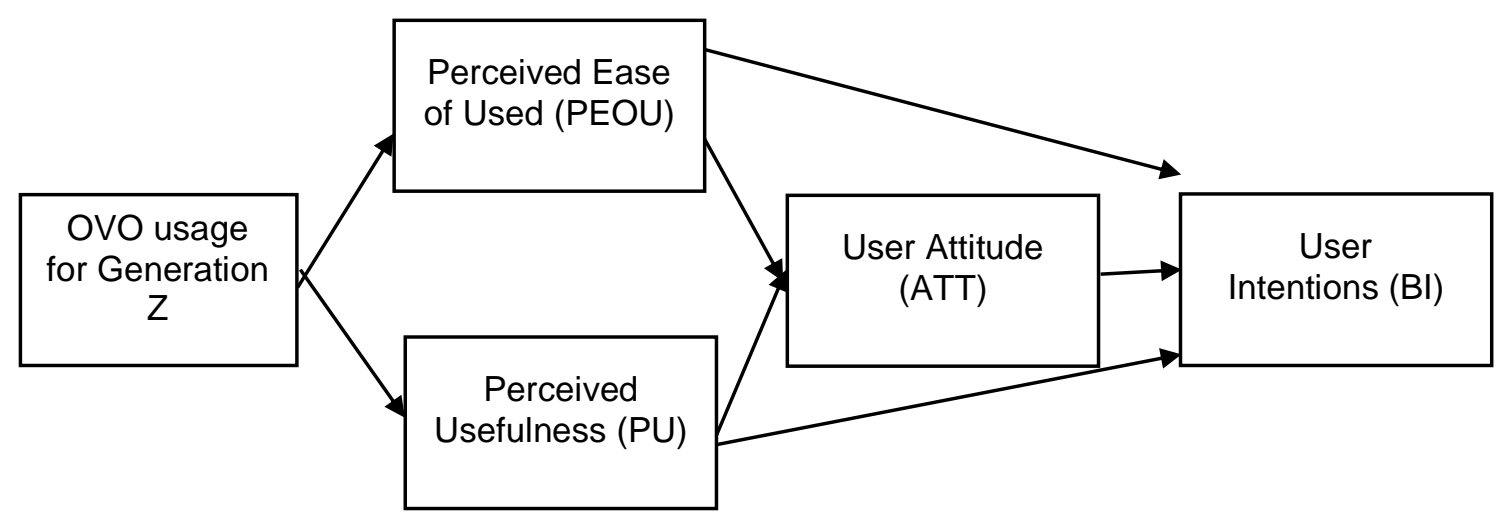

Figure 1. Research Model

\subsection{Hypotheses}

H1. Perceived Ease of Used (PEOU) has a significant positive effect on user attitudes (ATT).

H2. Perceived Ease of Used (PEOU) has a significant positive effect on user intentions (BI).

H3. Perceived Usefulness (PU) has a significant positive effect on user attitudes (ATT).

H4. Perceived Usefulness (PU has a significant positive effect on user intentions (BI).

H5. User Attitude (ATT) has a significant positive effect on user intentions (BI).

H6. User Attitude (ATT) will mediate perceptions eased of used (PEOU) on user intentions $(\mathrm{BI})$.

H7. User Attitude (ATT) will mediate perceived usefulness (PU) on user intentions (BI).

\section{METHODS}

Sugiyono (2016) states that the population is a collection of generalizations that have certain characteristics that the researcher has set for study. The population in this research were users of the OVO application in F\&B service industry whom is generation $\mathrm{Z}$ in Indonesia. The sample that is used in this research was selected using purposive sampling. Purposive 
sampling is a sampling technique in which the sample is selected by the researcher according to certain considerations (Sugiyono, 2016). Hair et al. (2014) argue that the minimum number of samples for multivariate research is 20 samples for each independent variable contained in the study. Because this research uses 2 independent variables, the minimum sample size required are 40 samples. However, in order for the research results to be more consistent, the researchers set a minimum sample size of 400 samples with the criteria of had use OVO application as a payment method in the F\&B service industry in the past year and aged between 17 and 25 years.

The first stage in data collection was carried out by researchers by making online questionnaire data using Google Form. The questionnaire then checked for validity and reliability using the SPSS application. Questionnaires that have been valid and reliable are then distributed again by researchers to all respondents by social media such as LINE, WhatsApp, Telegram, Instagram etc. until collected up to 487 respondents. the questionnaire data got screened afterwards. From all questionnaires, the researcher deleted 70 invalid questionnaires, leaving 417 questionnaires that is ready to get processed.

\subsection{Validity and Reliability Testing}

The validity test was conducted to test the ability of an indicator for measuring what indicator should measured (Sugiyono, 2016). The validity test was carried out by conducting a test on 30 respondents. Instrument of validity was carried out by comparing the $r$ count that has been measured using SPSS application against the $r$ table. questionnaire called valid if each the indicators has $r$ count $>r$ table, which in this research is 0.361 . Reliability test is conducted to test whether an instrument is reliable or not. A reliable instrument is an instrument that will produce the same consistent results when tested on the same object. (Sugiyono, 2016). The reliability test on this questionnaire was carried out by looking at the value of Cronbach's alpha which was tested using the SPSS application. A variable can be said to be reliable if it has a value of $\alpha>0.6$. The results of validity test and reliability in this study show the results of $r$ table that have exceeded 0.361 and Cronbach's alpha is more than 
0.6 so that this research questionnaire is valid and reliable and can be distributed to other respondents.

\section{RESULT AND DISCUSSION}

\subsection{Outer Model Testing}

Outer model testing is used to test the research validity and reliability. Validity is an indicator to measure what the indicator should be measured, while reliability is used to measure whether a data will show the same result of retesting the same object. The first test that must be done in testing the outer model is the factor loading test. The results of the factor loading test in this study are as follows:

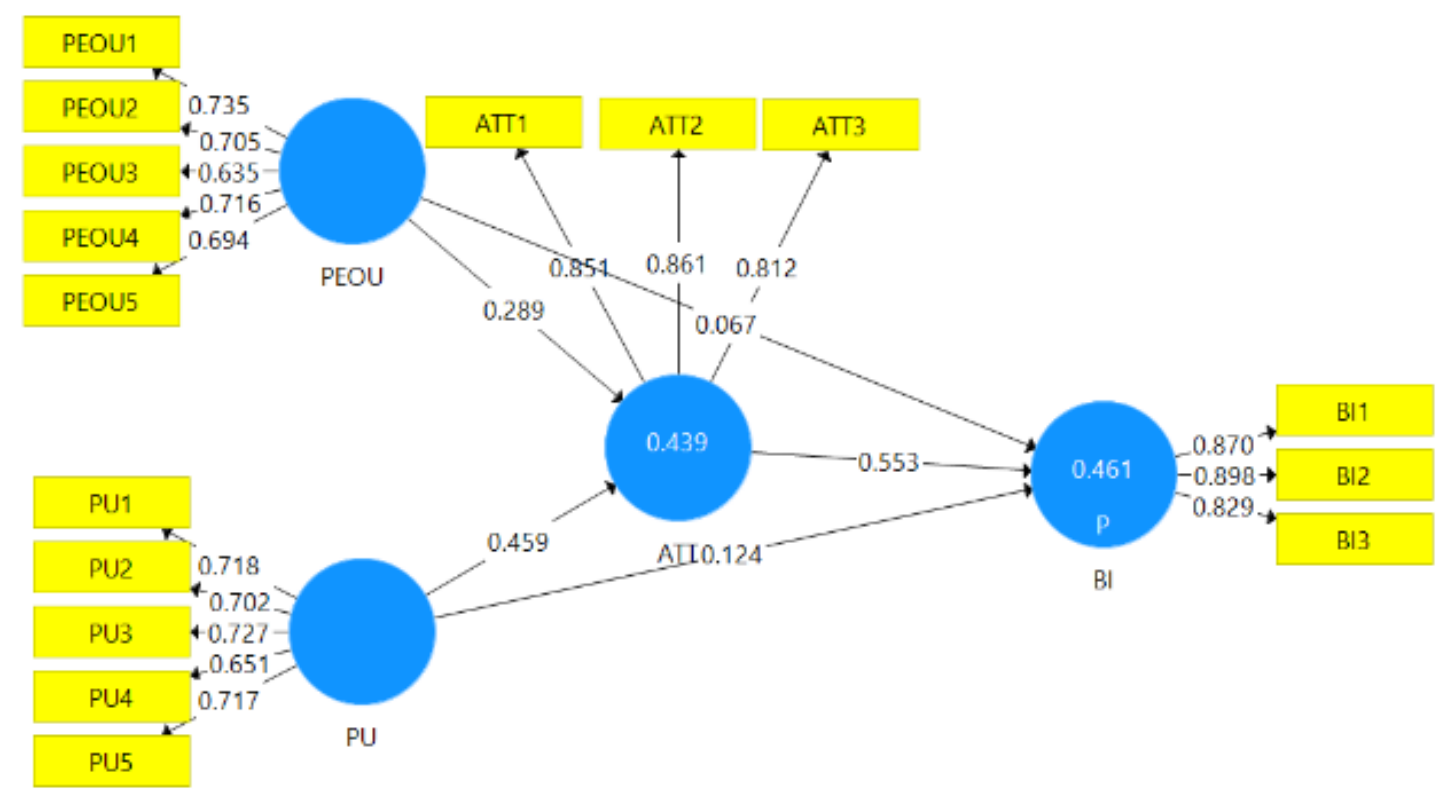

Figure 2. First Convergent Validity Test Results

Researchers argue that the minimum factor loading that each indicator must have should be $\geq 0.7$ (Hair et al., 2014). Factor loading test above resulted that, there are 3 indicators that has a value less than 0.7 , namely the PEOU3, PEOU5 and PU4 indicators. The researchers argue that if there are several indicators in 1 variable that have a factor loading value below the specified value, then one of the indicators that has the lowest loading value should be removed and recalculated (Hair et al., 2014). Based on the explanation above, the 
researcher removed 1 PEOU indicator and $1 \mathrm{PU}$ indicator which had the lowest loading factor value, namely PEOU3 (the OVO application user interface does not confuse users) and PU4 (the use of the OVO application minimizes errors in the payment process (such as wrong amount paid, miscalculated change, etc)) and retested. Outer loading test results can be seen in the following table on the next page

Table 1. Outer Loading Test Result

\begin{tabular}{|c|c|c|c|c|c|}
\hline Variabel & Indicator & $\begin{array}{l}\text { Factor } \\
\text { Loading }\end{array}$ & AVE & $\begin{array}{l}\text { Cronbach's } \\
\text { Alpha }\end{array}$ & $\begin{array}{l}\text { Composite } \\
\text { Reliability }\end{array}$ \\
\hline \multirow{4}{*}{$\begin{array}{l}\text { Perceived ease } \\
\text { of used }\end{array}$} & PEOU 1 & 0.729 & \multirow{4}{*}{0.542} & \multirow{4}{*}{0.717} & \multirow{4}{*}{0.824} \\
\hline & PEOU 2 & 0.743 & & & \\
\hline & PEOU 4 & 0.733 & & & \\
\hline & PEOU 5 & 0.731 & & & \\
\hline \multirow{4}{*}{$\begin{array}{l}\text { Perceived } \\
\text { Usefulness }\end{array}$} & PU 1 & 0.754 & \multirow{4}{*}{0.539} & \multirow{4}{*}{0.719} & \multirow{4}{*}{0.826} \\
\hline & PU 2 & 0.731 & & & \\
\hline & PU3 & 0.732 & & & \\
\hline & PU5 & 0.729 & & & \\
\hline \multirow{3}{*}{ User Attitude } & ATT 1 & 0.852 & \multirow{3}{*}{0.709} & \multirow{3}{*}{0.794} & \multirow{3}{*}{0.879} \\
\hline & ATT 2 & 0.860 & & & \\
\hline & ATT 3 & 0.812 & & & \\
\hline \multirow{3}{*}{ User Intention } & $\mathrm{Bl} 1$ & 0.870 & \multirow{3}{*}{0.750} & \multirow{3}{*}{0.833} & \multirow{3}{*}{0.900} \\
\hline & $\mathrm{BI} 2$ & 0.860 & & & \\
\hline & $\mathrm{BI} 3$ & 0.812 & & & \\
\hline
\end{tabular}

The outer model test results shows all data are valid and reliable. This can be seen from the AVE value which has exceeded 0.5 , Cronbach alpha exceeds 0.7 and the Composite reliability exceeds 0.7 .

\subsection{Inner Model Testing}

The inner model, often referred to as a structural model, is a test that is performed to test the relation between the latent variables under study. To test the connection between variables, two steps has been done by testing the $R^{2}$ value and the predictive relevance $\left(Q^{2}\right)$ value. The results of the $R^{2}$ and $Q^{2}$ tests are as follows:

Table 2. $Q^{2}$ dan $R^{2}$ Test Result

\begin{tabular}{|l|c|c|}
\hline \multicolumn{1}{|c|}{ Variabel } & $R^{2}$ & $Q^{2}$ \\
\hline ATT & 0.419 & 0.288 \\
\hline $\mathrm{BI}$ & $\mathbf{0 . 4 5 8}$ & $\mathbf{0 . 3 3 8}$ \\
\hline
\end{tabular}


The test result of $R^{2}$ shows a value of 0.419 for user attitude and 0.458 for user intention. This result indicates that the model for each of the exogenous variables in this research is good for explaining the intended endogenous variables. The calculation result of $\mathrm{R}^{2}$ which is worth 0.419 for the user attitude variable also indicates that $41 \%$ of the user's attitude has been explained by the independent variables contained in this research, namely perceived ease of use and perceived usefulness, and the remaining $59 \%$ is influenced by other factors that are not explained in the research. The intention of the user who has an $\mathrm{R}^{2}$ result is 0.458 indicating that the factors that influence the user's intention have been explained by the factors studied by $45 \%$, while the remaining $55 \%$ is influenced by other factors not explained in this study. while the $Q^{2}$ test results that exceed 0 indicate that the model that is owned has a good predictive relevance. The results of the calculation of $Q^{2}$ in this research are 0.288 for user attitudes and 0.338 for user intentions, this indicates that the variables in this study have a fairly good predictive relevance.

\subsection{Discussion}

Table 3 Results of the Path Coefficient and T-count on the Direct Effect

\begin{tabular}{|c|c|c|c|c|}
\hline Hypotheses & Direct Influences & $\begin{array}{c}\text { Path } \\
\text { Coefficient }\end{array}$ & T-Stat. & Information \\
\hline H1 & PEOU $\rightarrow$ ATT & 0.292 & 5.156 & Positive Significant \\
\hline H2 & PEOU $\rightarrow$ BI & 0.037 & 0.847 & Positive, Not Significant \\
\hline H3 & PU $\rightarrow$ ATT & 0.440 & 8.508 & Positive Significant \\
\hline H4 & PU $\rightarrow$ BI & 0.126 & 2.739 & Positive Significant \\
\hline H5 & ATT $\rightarrow$ BI & 0.571 & 13.067 & Positive Significant \\
\hline
\end{tabular}

The effect of perceived ease of use on user attitudes has a coefficient value of 0.292 which indicates a positive relation and a t-value of 5.156> 1.96 that shows a significant result. Therefore, it can be summarized that perceived ease of use has a positive and significant relation to user attitudes so that $\mathrm{H} 1$ is accepted. In the context of generation $\mathrm{Z}$, there are many things that can affect the perception of ease of use by generation $Z$, which one of the 
characteristics of generation $\mathrm{Z}$ who were born in the digital era, so they are often referred to as the internet generation (Mohammed, 2018). Unlike its predecessors, Generation Z has been exposed to technology from a very early age, this makes it easier for Generation $Z$ to understand and get used to when dealing with new technologies. In the context of using the OVO application, Generation Z was born in the technology era, will be easier to understand and will be more familiar with the use of the OVO application. This feeling will also make Generation Z feel more comfortable using the OVO application so that there will be positive feelings for Generation Z in liking the use of OVO applications in paying in the F\&B service industry.

The effect of perceived ease of use on user intentions has a coefficient value of 0.037 which indicates a positive relationship and a t-value of $0.847<1.96$ which indicates insignificant results. Therefore, it can be summarized that perceived ease of use has a positive but insignificant relationship to user intention so that $\mathrm{H} 2$ is rejected. In this generation $\mathrm{Z}$ context, this can be caused by several characteristics of generation $Z$, that are not having brand loyalty and growing up in the technology era (Mohammed, 2018). Growing up in the technology era, generation Z became more literate with the use of technology and made it easier for Generation $Z$ to understand of technology, which in the context of this research is mobile payment. Generation Z feels that every mobile payment application will bring exact convenience to themself so that convenience will not immediately lead to generation Z's intention to choose one of the mobile payments, but will still increase their positive attitude first which will then become one of the determining factors for themselves in choosing one of the mobile payments in the context of this research is OVO.

The effect of perceived benefits on user attitudes has a path coefficient value of 0.440 which indicates a positive relationship and a t-value of $8.508>1.96$ which indicates a significant result. Therefore, it can be concluded that perceived benefits have a positive and significant relationship with user attitudes so that $\mathrm{H} 3$ is accepted. In the context of generation $Z$, there are many things that can affect the perception of benefits possessed by generation $Z$, one of which is the characteristic of generation $Z$ who prefers instant things (Purnomo et 
al., 2016). Generation Z, who was born and grew up in the technological era, has made generation $\mathrm{Z}$ accustomed to the use of technology that makes life more practical. This has helped develop the characteristics of the $\mathrm{Z}$ generation, which is always looking for practical solutions compared to conventional processes which take longer. The use of OVO application in the F\&B service industry creates an instant impression compared to other methods such as cash payments, thus making Generation Z feel that OVO application brings benefits that speed up the payment process. When generation $Z$ feels that the OVO application in paying in the F\&B service industry makes payments faster, there will be a positive attitude to prefer using the OVO application payment system over other methods.

The effect of perceived usefulness on user intention has a path coefficient value of 0.126 which indicates a positive relationship and a t-count value of $2.739>1.96$ which indicates a significant result. Therefore, it can be concluded that perceived usefulness have a positive and significant relationship with user intention so that $\mathrm{H} 4$ is accepted. This result implies that perceived usefulness are related to Generation Z's intention to use OVO applications such as speeding up the payment process, saving time and so on. Al-Maghrabi \& Dennis (2011) stated that perceived benefits have a positive effect on individual intention to use e-commerce.

The influence of user attitudes on user intentions has a path coefficient value of 0.571 which indicates a positive relationship and a t-value of $13.067>1.96$ which indicates a significant result. Therefore, it can be concluded that user attitudes have a positive and significant relation to user intentions so that $\mathrm{H} 5$ can be accepted. In generation $\mathrm{Z}$ context, it can be said that when generation $Z$ feels that using OVO applications is a wise action, the feeling will form a positive attitude and then will be encourage user to use OVO applications continuously when user wants to make a payment in the F\&B service industry.

Table 4. Result of Path Coefficient, T-count and Mediation Relation on Indirect Effect

\begin{tabular}{|c|c|c|c|c|c|}
\hline Hypotheses & Indirect Effect & $\begin{array}{c}\text { Path } \\
\text { Coefficient }\end{array}$ & T-Stat & $\begin{array}{c}\text { Mediation } \\
\text { Relation }\end{array}$ & Information \\
\hline $\mathrm{H} 6$ & PEOU $\rightarrow$ ATT $\rightarrow \mathrm{BI}$ & 0.167 & 4.786 & $\begin{array}{c}\text { Full } \\
\text { Mediation }\end{array}$ & $\begin{array}{c}\text { Positive } \\
\text { Significant }\end{array}$ \\
\hline $\mathrm{H} 7$ & $\mathrm{PU} \rightarrow \mathrm{ATT} \rightarrow \mathrm{BI}$ & 0.251 & 7.199 & $\begin{array}{c}\text { Partial } \\
\text { Mediation }\end{array}$ & $\begin{array}{c}\text { Positive } \\
\text { Significant }\end{array}$ \\
\hline
\end{tabular}


The effect of perceived ease of use on user intentions through user attitudes has a path coefficient value of 0.167 which indicates a positive relationship and the t-count value is $4.789>$ 1.96 which indicates a significant result. So it can be concluded that perceived ease of use has a positive and significant relation to user intentions through user attitudes as a mediating variable so that $\mathrm{H} 6$ is accepted. In the context of Generation $\mathrm{Z}$, the generation born in the technology era made it easy for Generation $Z$ to learn and understand in using technology. This causes generation $Z$ to feel that every mobile payment application is easy to learn and use so that convenience will indirectly affect its intention to use a particular mobile payment service. Even so, a mobile payment service is easier to use will give a user a familiar and comfortable feeling. This feeling will increase user positive attitude which will then make generation $\mathrm{Z}$ feel comfortable and have the intention of using the OVO application as payment method in the F\&B service industry.

The effect of perceived usefulness on user intentions through user attitudes has a path coefficient value of 0.251 that shoes a positive relation and the t-value is $7,199>1.96$ with outcome of a significant result. So it can be concluded that perceived usefulness have a positive and significant relation for user intentions through user attitudes as a mediating variable so that $\mathrm{H} 7$ is accepted. In the context of generation $\mathrm{Z}$, the characteristic of generation Z who likes instant process made Generation Z feel that using the OVO application that speeds up the payment process is actually enough to increase its intention of using OVO application. However, this perception will also increase the positive attitude which Generation Z already has, where Generation Z will felt that using the OVO application is wise because it brings benefits to itself. The positive attitude that has emerged in Generation $Z$ will further strengthen the intention of Generation $Z$ so that Generation $Z$ will be more confident in choosing to use the OVO application as tools of payment in the F\&B service industry. 


\section{CONCLUSIONS}

The results show that there are direct and indirect influences that affect the user's intention of using OVO application for payment in the F\&B service industry. perceived ease of use and perceived usefulness have a significant positive effect on user attitudes. Perceived ease of use and user attitudes have a positive and significant effect on user intentions. Perceived ease of use has a positive but insignificant effect on user intention. In addition to the direct effect, there is also an indirect effect where the perceived ease of use and perceived benefits will indirectly influence the user's intention by increasing the user's attitude before increasing the user's intention.

According to the results of this study for OVO applications, it is evident that the strongest reason why generation $Z$ uses OVO is mainly because OVO makes payments faster and the entire OVO application process can be easily accessed. Therefore, researchers suggest that OVO should further improve and speed up its payment system. This can be done by adding and improving some features in the OVO application payment such as by adding the OVO pay later feature and one click top up feature to increase the speed of payment process. For the subsequent research, researchers provide suggestions for develop and reviewing this research because there are still inconsistencies results of previous research. In addition, researchers provide suggestions to apply this result or research to every generations. It aims to find generalizing the results to get more general results.

\section{REFERENCES}

Ajzen, I. (1991). The theory of planned behavior. Organizational Behavior and Human Decision Processes, 50(2), 179-211. https://doi.org/10.1016/0749-5978(91)90020-T

Al-Maghrabi, T., \& Dennis, C. (2011). What drives consumers' continuance intention to eshopping?: Conceptual framework and managerial implications in the case of Saudi Arabia. International Journal of Retail and Distribution Management, 39(12), 899-926. https://doi.org/10.1108/09590551111183308

Annur, C. M. (2020, January). Transaksi OVO tembus 1 miliar di tahun 2019. Katadata.Co.ld. https://tirto.id/transaksi-ovo-tembus-1-miliar-di-tahun-2019-eroV

Apidana, Y. H., Suroso, A., \& Setyanto, R. P. (2020). Model penerimaan teknologi mobile payment pada digital native dan digital immigrant di Indonesia. Jurnal Ekonomi, Bisnis, Dan Akuntansi, 21(4). https://doi.org/10.32424/jeba.v21i4.1542

Aria, P. (2019, September). OVO jadi dompet digital terbesar di Indonesia berkat ekosistem 
Grab. Katadata.Co.ld. https://katadata.co.id/pingitaria/digital/5e9a4e6c28da0/ovo-jadidompet-digital-terbesar-di-indonesia-berkat-ekosistem-grab

Cousins, J., Foskett, D., Graham, D., Hollier, A., Cousins, J., Foskett, D., Graham, D., \& Hollier, A. (2019). Food and beverage service. In Food and Beverage Management (5th ed.). https://doi.org/10.23912/9781911635109-4144

Davis, F. D. (1989). Perceived usefulness, perceived ease of use, and user acceptance of information technology. MIS Quarterly: Management Information Systems, 13(3), 319339. https://doi.org/10.2307/249008

Davis, F. D. (1993). User acceptance of information technology: System characteristics, user perceptions and behavioral impacts. International Journal of Man-Machine Studies, 38(3), 475-487. https://doi.org/10.1006/imms.1993.1022

Febria, M., \& Oktavio, A. (2020). Peran positive emotion sebagai intervening variable antara sales promotion dan impulsive buying behaviour pada pengguna e-wallet pengunjung Tunjungan Plaza Surabaya. Jurnal Manajemen Pemasara, 14(2), 67-76. https://doi.org/10.9744/pemasaran.14.2.67

Gupta, K., \& Arora, N. (2019). Investigating consumer intention to accept mobile payment systems through unified theory of acceptance model: An Indian perspective. South Asian Journal of Business Studies, 9(1), 88-114. https://doi.org/10.1108/SAJBS-03-2019-0037

Hair, J. F. J., Black, W. C., Babin, B. J., \& Anderson, R. E. (2014). Multivariate data analysis. Exploratory data analysis in business and economics. In British Library Cataloguing-inPublication Data (7th ed.). Pearson Education Limited.

Hill, R. J., Fishbein, M., \& Ajzen, I. (1977). Belief, attitude, intention and behavior: An introduction to theory and research. Contemporary Sociology, 6(2), 244. https://doi.org/10.2307/2065853

Kucukusta, D., Law, R., Besbes, A., \& Legohérel, P. (2015). Re-examining perceived usefulness and ease of use in online booking: The case of Hong Kong online users. International Journal of Contemporary Hospitality Management, 27(2), 185-198. https://doi.org/10.1108/IJCHM-09-2013-0413

Latief, F., \& Nur, Y. (2019). Technology Acceptance Model (Tam) terhadap minat konsumen sistem pembayaran Gopay pada layanan Gojek. Bongaya Journal for Research in Management (BJRM), 2(2), 1-11. https://doi.org/10.37888/bjrm.v2i2.201

Mohammed, A. B. (2018). Selling smartphones to Generation Z: Understanding factors influencing the purchasing intention of smartphone. International Journal of Applied Engineering Research, 13(6), 3220-3227. http://www.ripublication.com

Nguyen, T. T. H., Nguyen, N., Nguyen, T. B. L., Phan, T. T. H., Bui, L. P., \& Moon, H. C. (2019). Investigating consumer attitude and intention towards online food purchasing in an emerging economy: An extended TAM approach. Foods, 8(11). https://doi.org/10.3390/foods8110576

Purnomo, A., Ratnawati, N., \& Aristin, N. F. (2016). Pengembangan pembelajaran blended learning pada generasi Z. Jurnal Teori Dan Praksis Pembelajaran IPS, 1(1), 70-76. https://doi.org/10.17977/um022v1i12016p070

Putri, N., Rahadi, R. A., Resti, N., Putri, R., \& Murtaqi, I. (2017). A conceptual study on the use of electronic payment instruments among Generation $Z$ in Bandung City. Journal of Global Business and Social Entrepreneurship (GBSE), 3(9), 32-40. https://www.researchgate.net/publication/322356949

Sugiyono. (2016). Metode penelitan kuantitatif, kualitatif dan R\&D. In Alfabeta. Alfabeta.

Wu, B., \& Chen, X. (2017). Continuance intention to use MOOCs: Integrating the technology acceptance model (TAM) and task technology fit (TTF) model. Computers in Human Behavior, 67, 221-232. https://doi.org/10.1016/j.chb.2016.10.028 